\title{
The first record of the pharaoh cardinal fish, Apogonichthyoides pharaonis (Actinopterygii: Perciformes: Apogonidae), from Libyan waters
}

\author{
Sara A.A. Al MABRUK ${ }^{1}$, Bruno ZAVA ${ }^{2,3}$, Abdulghani ABDULGHANI ${ }^{4}$, \\ Maria CORSINI-FOKA ${ }^{5}$, Alan DEIDUN ${ }^{6}$ \\ 1 Zoology Department, Faculty of Science, Omar Al-Moukhtar University, El Bayda, Libya \\ 2 Museo Civico di Storia Naturale, Comiso (Ragusa), Italy \\ 3 Wilderness Studi Ambientali, Palermo, Italy \\ 4 Department of Marine Resources, Omar Al-Moukhtar University, El Bayda, Libya \\ 5 Hellenic Centre for Marine Research, Institute of Oceanography, Hydrobiological Station of Rhodes, Greece \\ 6 Department of Geosciences, University of Malta, Msida, Malta
}

http://zoobank.org/965639CF-AD45-4701-A6C9-0C08ACA0DEF7

Corresponding author: Bruno ZAVA (wildernessbz@hotmail.com)

Academic editor: Paraskevi Karachle • Received 21 November 2020 • Accepted 16 January 2021 • Published 31 March 2021

Citation: Al Mabruk SAA, Zava B, Abdulghani A, Corsini-Foka M, Deidun A (2021) The first record of the pharaoh cardinal fish, Apogonichthyoides pharaonis (Actinopterygii: Perciformes: Apogonidae), from Libyan waters. Acta Ichthyologica et Piscatoria 51(1): 113-118. https://doi.org/10.3897/aiep.51.63504

\section{Abstract}

The occurrence of the pharaoh cardinalfish, Apogonichthyoides pharaonis (Bellotti, 1874), is documented for the first time from the Libyan waters, after two subsequent findings reported in September and November 2020 in the far eastern region of the country. The location of these findings represents the westernmost area of distribution in the southern Mediterranean for this species, which has the western Indian Ocean and Red Sea origin and which entered into the Mediterranean via the Suez Canal.

\section{Keywords}

Non-Indigenous Species (NIS), Lessepsian migration, Suez Canal, citizen science, southern Mediterranean, spear fishing

\section{Introduction}

There is only one member of the cardinal fish family (Apogonidae) native to the Mediterranean, the Mediterranean cardinal fish, Apogon imberbis (Linnaeus, 1758), while at least five non-indigenous members of the same family have been recorded to date from the basin. These include the spotfin cardinal, Jaydia queketti (Gilchrist, 1903), the Smith's cardinalfish' Jaydia smithi Kotthaus, 1970, the broadbanded cardinalfish, Ostorhinchus fasciatus (White, 1790), the Indian Ocean twospot cardinalfish, Cheilodipterus novemstriatus (Rüppell, 1838), and the pharaoh cardinalfish, Apogonichthyoides pharaonis (Bellotti, 1874), all introduced via the Suez Canal
(Lessepsian migrant fishes) (Rothman et al. 2013; Irmak and Engin 2015).

Apogonichthyoides pharaonis is native to the Red Sea, the Persian Gulf, and the western Indian Ocean (Gon 2000; Gon and Randall 2003). The species was first recorded in the basin at Port Said, Egypt, in 1924 (Norman 1927) and later off the Palestinian coasts before 1946 , misidentified as Apogonichthyoides taeniatus (Cuvier, 1828) (see Haas and Steinitz 1947; Golani 2010). The species was subsequently recorded from Cyprus in 1961 (Demetropoulos and Neocleous 1969), Lebanon in 1962 (George et al. 1963), from south-eastern Turkey in 1984 (Mater and Kaya 1987), from Syria in 1992 (Sbaihi and Saad 1995), from the south-eastern Aegean Sea, at Symi 
Island, Greece, in 1982 (Zachariou-Mamalinga 1990), and at Rhodes Island, Greece, and the Datça Peninsula region, Turkey, in 2002 (Corsini-Foka et al. 2004; Öz et al. 2007) (Fig. 1). The species is currently classified as an established non-indigenous species in the Levantine Sea, being regularly caught as bycatch in the artisanal fishery (Carpentieri et al. 2009; Anonymous 2010) in relatively shallow waters of Egypt (Ragheb et al. 2019), Turkey (Bilge et al. 2019), Cyprus (Iglésias and Frotté 2015), Lebanon (Carpentieri et al. 2009), and Greece (Corsini-Foka et al. 2014; Corsini-Foka and Kondylatos 2015).

In this study, the record of $A$. pharaonis is documented for the first time in the Libyan waters, being the species not yet reported in recent literature on marine non-indigenous species of the country (Shakman et al. 2019 and references therein; Abdelghani et al. 2020; Bariche et al. 2020; Osca et al. 2020). The locations of the two subsequent findings of $A$. pharaonis described in this paper represent the westernmost Mediterranean area of colonization of this non-indigenous fish along the southern shores of the basin.

\section{Material and methods}

On 19 September 2020, a spear fisher submitted photos to the social media citizen science platform for Libyan waters called 'Marine Biology in Libya' (https://www. facebook.com/MarineBiologyinlibya) of an unknown fish he had just caught. The catch was made on rocky bottom interrupted by sand at a depth of approximately $1.5 \mathrm{~m}$, along the coast of the Al Burdi (Bardia) region in the far eastern extremity of Libya, not far from the Egyptian border $\left(31^{\circ} 46^{\prime} 45^{\prime \prime} \mathrm{N}, 25^{\circ} 04^{\prime} 40^{\prime \prime} \mathrm{E}\right)$ (Fig. 1). The same sports fisher preserved in a freezer the specimen (specimen A), which was retrieved by one of us (SAM), to enable the assessment and measurement of its main morphometric and meristic attributes. Measurements were taken with a caliper to the nearest $0.01 \mathrm{~mm}$, following Bauchot (1987). The sample is stored in formaldehyde solution at the fish collection of the Omar Al-Moukhtar University, El Bayda, Libya. The specimen was identified following Gon (1986, 2000), Gon and Randall (2003), and Golani et al. (2013).

On 17 November 2020, a recreational fisherman posted pictures of the second specimen of $A$. pharaonis (specimen B) on a Facebook group of spear fishing lovers (https://www.facebook.com/groups/377703789082199/?ref=sh are). The fish was captured with a fishing rod at $2 \mathrm{~m}$ of depth, on a mixed rocky and sandy bottom, off Tobruk city $\left(32^{\circ} 04^{\prime} 20^{\prime \prime} \mathrm{N}, 23^{\circ} 58^{\prime} 09^{\prime \prime} \mathrm{E}\right)$, western to the previous site (Fig. 1). The sample was returned to the sea. The specimen was identified through examination of photos taken immediately after its capture.

\section{Results}

The specimen A, slightly damaged, featured the following meristic characters: D1: VII; D2: I + 9 (the fourth

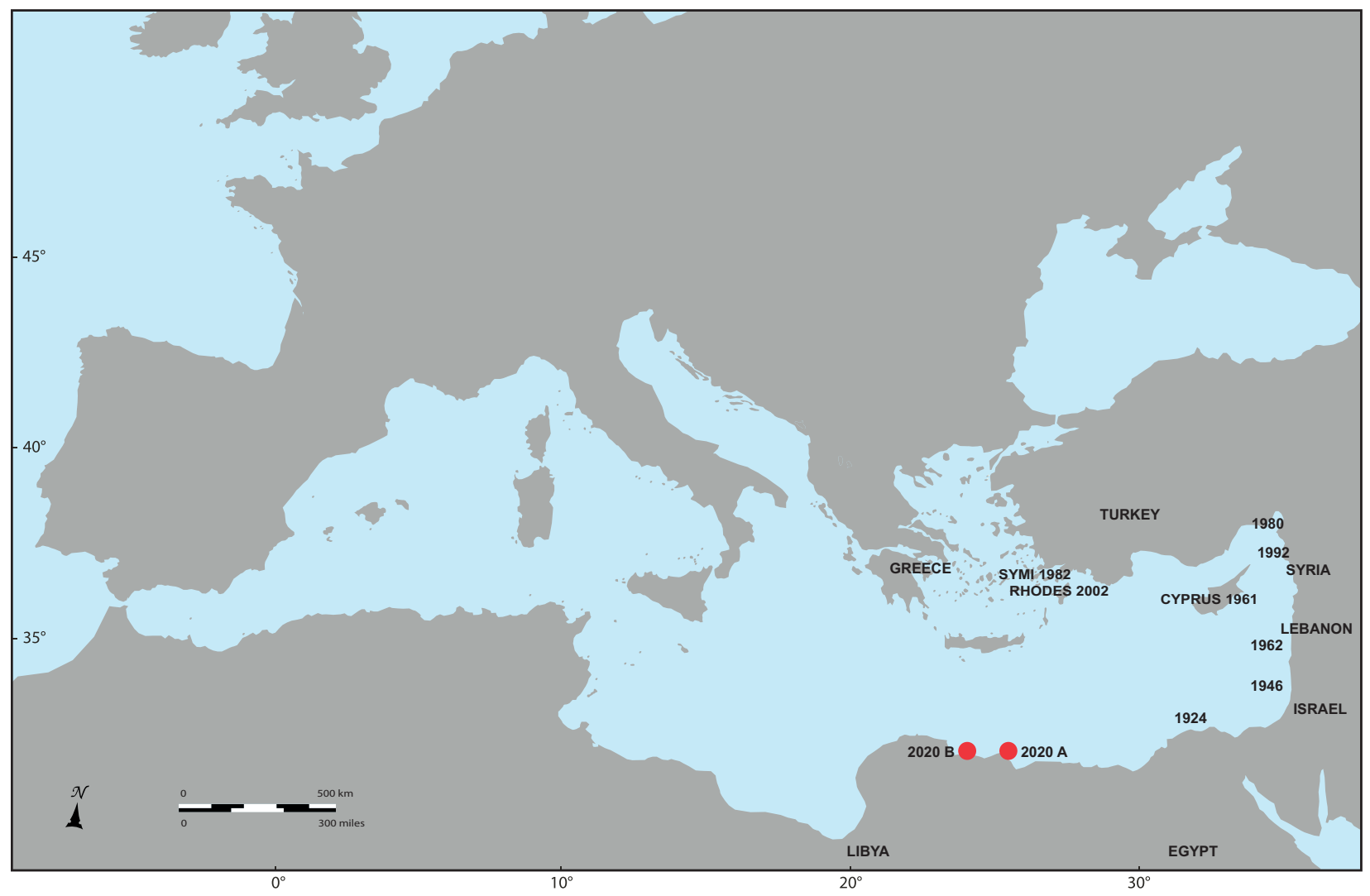

Figure 1. Locations and dates of first records of Apogonichthyoides pharaonis in the Mediterranean Sea, updated with the two findings in Libyan waters in 2020 (red bullets; A. specimen from Al Burdi; B. specimen from Tobruk). 
soft ray broken); P: 15; A: II + 8; V: I + 5; LL: 24; Gill rakers: 17. The fish measured $52.92 \mathrm{~mm}$ in total length (TL), $40.81 \mathrm{~mm}$ in standard length (SL), and weighed 2.6 g. The main proportions were: body depth 2.2 and head length 2.4 in SL; snout length 4.7, eye diameter 3.3 and upper-jaw length 1.9 , all in head length; caudal peduncle depth 1.2 in its length; peduncle length 5.1 in SL. The fish presented a body laterally compressed, pale brown with two distinct dorsal fins, pelvic fin origin under the base of the pectoral fin, truncate tail, and large eye size. Color in fresh specimens: four dark vertical bars, the first running under the first dorsal fin, the second under posterior half of the second dorsal fin and extending to the tip of the spine of the second dorsal fin and to the tip of second spine in anal fin, the third, faint, on the caudal peduncle and the fourth on caudal fin base (Fig. 2A, B); a dark caudal spot visible (Fig. 2A, B); a black and silvery 'eye-spot' (ocellus) on the right flank of specimen A (left side damaged) and on both sides of specimen B, within the first black vertical bar under the lateral line (Fig. 2A detail, B); anterior part of first dorsal fin dark, second dorsal and anal fins dusky (except the dark extension of the second bar), pectoral and caudal fin pale, ventral fin dusky. The gross morphology and livery of the two specimens, along with the morphometric and meristic attributes of the specimen A were generally consistent with $A$. pharaonis, as described in Gon (2000), Gon and Randall (2003), Goren et al. (2009a) and Golani et al. (2013). The common TL of the species ranges between $5 \mathrm{~cm}$ and $8 \mathrm{~cm}$, with a maximum of $12 \mathrm{~cm}$ (Golani et al. 2013). Citing Gon and Randall (2003), the smallest mature female ever recorded for the species had a TL of $3.4 \mathrm{~cm}$. The $A$. pharaonis specimen A recorded in the presently reported study can be thus considered to represent a young adult stage of the species.

\section{Discussion}

The gross morphology and livery of $A$. pharaonis is similar to that of the congeneric and sympatric Apogonichthyoides pseudotaeniatus (Gon, 1986), A. taeniatus, and Apogonichthyoides timorensis (Bleeker, 1854), following
Gon and Randall (2003). Apogonichthyoides pseudotaeniatus differs in lacking a bar on the caudal peduncle. In A. taeniatus, the second bar originates at the rear part of the second dorsal-fin base, usually fades out on the middle of the body, and does not extend onto the second dorsal fin. In addition, $A$. taeniatus has a caudal spot, but no bar on the caudal-fin base and 5-6 narrow dusky stripes along the body, which are never present in A. pharaonis, and usually 3 median predorsal scales. The color pattern of $A$. timorensis is similar to that of $A$. pharaonis, but the first never has an eye-spot between the lateral line and pectoral fin, and its bars are less distinct. Furthermore, according to the same authors, A. pharaonis is similar to Apogonichthyoides nigripinnis (Cuvier, 1828), whose distribution is restricted to the eastern Indian and western Pacific oceans, while A. pharaonis occurs in the western Indian Ocean. Also, both species have the ocellus below the lateral line, but $A$. nigripinnis lacks the two wide dark bars below the dorsal fins. They differ furthermore in some morphometric and meristic characteristics.

The Apogonidae species known from the Red Sea and the Arabian Sea live mainly in shallow waters and inhabit coral reefs and rocky areas; some species can be found on soft bottoms, seagrass beds, on silty reefs and on mangroves (Smith 1961; Gon and Randall 2003; Debelius 2011). Cardinal fish species of the Red Sea are nocturnal planktivorous predators, hidden by day (Goren et al. 2009b), but some species are active during sunlight (Debelius 2011). Among the apogonid migrants, A. pharaonis occurs on mangroves, seagrass beds, and on silty reefs in its native range (Gon 2000) and in the Mediterranean occupies prevalently seagrass meadows as well as soft bottom habitats (sandy and muddy) (Goren et al. 2009a; Corsini-Foka et al. 2014; Corsini-Foka and Kondylatos 2015), although it may be observed in front of rocks, in sandy or weedy shallow areas (MCF pers. comm.). The specimens of $A$. pharaonis under study were found on very shallow rocky bottom interrupted by sand. The preferred depth range of $A$. pharaonis, which extends up to $50 \mathrm{~m}$, partly overlaps with the depth range of the native Mediterranean A. imberbis, which occupies rocky reefs and seagrass habitats at 2-70 $\mathrm{m}$ and more (Goren et al. 2009a; Froese and Pauly 2019).
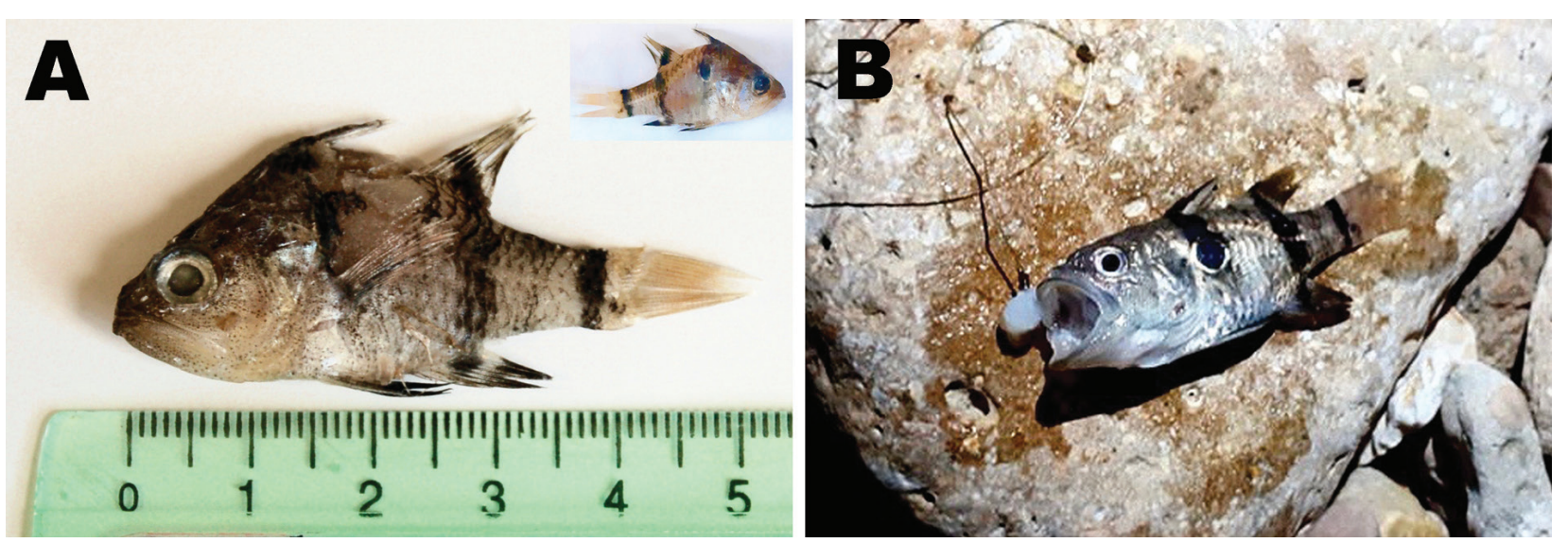

Figure 2. Apogonichthyoides pharaonis from Libya (A. specimen from Al Burdi; B. specimen from off Tobruk). 
In their native range, $O$. fasciatus inhabits coastal reefs, in sandy or algal-dominated areas, J. smithi occurs on silty bottom, and $J$. queketti is a benthopelagic fish (Froese and Pauly 2019). In the Mediterranean, all three above-mentioned Lessepsian migrant species have been collected on bare muddy-silt bottoms (Golani et al. 2008; Goren et al. 2009a, 2009b) and a possible reversion of feeding habits from zooplankton to zoobenthos needs yet to be determined (Goren et al. 2009b). The last recorded C. novemstriatus lives in front of holes and under ledges of coral or rocky reefs; frequently it finds refuge among the spines of sea-urchins of the genus Diadema in groups of up to about 30 individuals (Gon and Randall 2003). In the Mediterranean, $C$. novemstriatus lives on various types of hard bottoms and near crevices (Rothman et al. 2013), and it has been observed among the spines of the already established non-indigenous sea urchin Diadema setosum in Rhodes Island (Ragkousis et al. 2020). The present species richness of Lessepsian apogonids, their rapid spread and abundance within the eastern Mediterranean are potentially of marine conservation and management concern for native communities, due to their establishment in diversified habitats.

It is interesting to note that the pharaoh cardinalfish is the earliest colonizer of Mediterranean waters among the Lessepsian apogonids, and it apparently expanded slowly its distribution in Levantine waters. The other four apogonid species mentioned above have been all recorded from the Mediterranean basin many decades later than the initial A. pharaonis record, between 2004 and 2010, and they appear to be extending rapidly their distribution range in the Levant (Rothman et al. 2013 and references therein), easily adapting to and establishing in the new environment. In particular, J. queketti, first recorded in the southern Turkey in 2004, has been observed in the south-eastern Aegean waters of Turkey in 2009 and again in 2014 (Akyol and Ünal 2015), while C. novemstriatus, first recorded along the Mediterranean coasts of Israel in 2010, has been detected at Rhodes, Greece, in 2020 (Ragkousis et al. 2020).

Nevertheless, it should be emphasized that the successive enlargements of the Suez Canal could be associated with the increase of new introductions of tropical and subtropical species from the Red Sea (Galil et al. 2017) and that the warming of Mediterranean waters due to climate change facilitates their expansion (Zenetos and
Galanidi 2020). Furthermore, the intensification all over the basin of research efforts and of underwater observations performed by citizen scientists during recent years has greatly contributed to the early detection of new or overlooked non-indigenous biota in many countries at a much faster pace than in the pre-citizen science era (Roy et al. 2018; Katsanevakis et al. 2020).

In this work, the occurrence of the Lessepsian migrant fish $A$. pharaonis, probably overlooked for a long time, is documented herewith for the first time in Libyan waters, due to the input of citizen science information. The Mediterranean Sea is a hotspot of biological invasions and introduced species are one of the major threats to Mediterranean biodiversity (Coll et al. 2010), resulting in changes of composition, function, and service of marine biocommunities, mainly in the eastern part of the basin (Katsanevakis et al. 2014, 2020). More than 100 alien fish species of the Red Sea/Indo-Pacific Ocean origin have been introduced via the Suez Canal into the Mediterranean basin (Golani and Fricke 2018), the majority established and integrated within the native food webs; many of these species do not have a commercial value and they are discarded in fishery activities, while other species dominate the fish catches, often with socio-economic and ecological impacts (Galil et al. 2017; Katsanevakis et al. 2020). Monitoring the expansion and abundance of non-indigenous species in the Mediterranean waters is of huge importance at the national and international level in order to contribute to the assessment of the quality of the waters of the basin and to manage its resources and sustainability, under the pressure of biological invasions and other factors (Anonymous 2020). The record of $A$. pharaonis in Libya not only adds knowledge on the poorly known ichthyofauna diversity of the whole country but contributes to fill gaps concerning the range distribution of this alien species in the Mediterranean basin.

\section{Acknowledgments}

The authors are indebted to Mohamed Boubaker and Mohamed Reziq Al Mezini, the fishers who caught the fish specimens reported within this study. The authors warmly thank also two reviewers for their insightful and constructive comments on the first version of the manuscript.

\section{References}

Abdelghani A, Al Mabruk SA, Crocetta F, Golani D (2020) The streamlined rabbitfish Siganus argenteus (Quoy \& Gaimard, 1825) in the Mediterranean Sea. Thalassas 37:287-290. https://doi.org/10.1007/ s41208-020-00259-Z

Akyol O, Ünal V (2015) Additional record of the Lessepsian Apogon queketti Gilchrist, 1903 (Osteichthyes: Apogonidae) from the Aegean Sea (Gökova Bay, Turkey). Journal of Applied Ichthyology 31(3): 536-537. https://doi.org/10.1111/jai.12702
Anonymous (2010) Report of the Sub-Regional Technical Meeting on the Lessepsian migration and its impact on Eastern Mediterranean fishery. Scientific and Institutional Cooperation to Support Responsible Fisheries in the Eastern Mediterranean. GCP/INT/041/ECGRE-ITA/TD-04. Athens.

Anonymous (2020) The state of Mediterranean and Black Sea fisheries 2020. General Fisheries Commission for the Mediterranean. FAO, Rome, 172 pp. https://doi.org/10.4060/cb2429en 
Bariche M, Al-Mabruk S, Ateş M, Büyük A, Crocetta F, Dritsas M, Edde D, Fortič A, Gavriil E, Gerovasileiou V, Gökoğlu M, Huseyinoglu F, Karachle P, Kleitou P, Terbiyik Kurt T, Langeneck J, Lardicci C, Lipej L, Pavloudi C, Pinna M, Rizgalla J, Rüştü Özen M, Sedano F, Taşkin E, Yildiz G, Zangaro F (2020) New alien Mediterranean biodiversity records (March 2020). Mediterranean Marine Science 21(1): 129-145. https://doi.org/10.12681/mms.21987

Bauchot M-L (1987) Poissons osseux. In: Fischer W, Bauchot M-L, Schneider M (Eds) Fisches FAO d'identification des espèces pour les besoins de la pêche. (Revision 1). Méditeranée et Mer Noire. Zone de pêche 37. Vértebrés. Vol. 2. FAO, Rome, 892-1422.

Bilge G, Filiz H, Yapici S, Tarkan AS, Vilizzi L (2019) A risk screening study on the potential invasiveness of Lessepsian fishes in the south-western coasts of Anatolia. Acta Ichthyologica et Piscatoria 49(1): 23-31. https://doi.org/10.3750/AIEP/02422

Carpentieri P, Lelli S, Colloca F, Mohanna C, Bartolino V, Moubayed S, Ardizzone GD (2009) Incidence of Lessepsian migrants on landings of the artisanal fishery of south Lebanon. Marine Biodiversity Records 2: e71. https://doi.org/10.1017/S1755267209000645

Coll M, Piroddi C, Steenbeek J, Kaschner K, Ben Rais Lasram F, Aguzzi J, Ballesteros E, Bianchi CN, Corbera J, Dailianis T, Danovaro R, Estrada M, Froglia C, Galil BS, Gasol JM, Gertwagen R, Gil J, Guilhaumon F, Kesner-Reyes K, Kitsos M-S, Koukouras A, Lampadariou N, Laxamana E, López-Fé de la Cuadra CM, Lotze HK, Martin D, Mouillot D, Oro D, Raicevich S, Rius-Barile J, Saiz-Salinas JI, San Vicente C, Somot S, Templado J, Turon X, Vafidis D, Villanueva R, Voultsiadou E (2010) The Biodiversity of the Mediterranean Sea: Estimates, patterns, and threats. PLoS One 5(8): e11842. https://doi. org/10.1371/journal.pone.0011842

Corsini-Foka M, Kondylatos G (2015) Native and alien ichthyofauna in coastal fishery of Rhodes (eastern Mediterranean) (2002-2010). Conference Abstracts of the XV European Congress of Ichthyology, 7-11 September 2015, Porto, Portugal. Frontiers in Marine Science. https://doi.org/10.3389/conf.FMARS.2015.03.00069

Corsini-Foka M, Kondylatos G, Economidis PS (2004) Occurrence of the Lessepsian species Portunus pelagicus (Crustacea) and Apogon pharaonis (Pisces) in the marine area of Rhodes Island. Mediterranean Marine Science 5(1): 5-17. https://doi.org/10.12681/mms.213

Corsini-Foka M, Kondylatos G, Santorinios E (2014) The role of the Aquarium of Rhodes (eastern Mediterranean Sea) on raising public awareness to marine invasions, with a note on the husbandry and trade of marine aliens. Cahiers de Biologie Marine 55(2): 173-182. https://doi.org/10.21411/CBM.A.8221A005

Debelius H (2011) Red Sea reef guide. IKAN-unterwasserarchiv, Frankfurt, Germany.

Demetropoulos A, Neocleous D (1969) The fishes and crustaceans of Cyprus. Fisheries Bulletin of Cyprus 1: 1-21.

Froese R, Pauly D (Eds.) (2019) FishBase. World Wide Web electronic publication. www.fishbase.org [version 12/2019]

Galil BS, Marchini A, Occhipinti-Ambrogi A, Ojaveer H (2017) The enlargement of the Suez Canal-Erythraean introductions and management challenges. Management of Biological Invasions 8(2): 141-152. https://doi.org/10.3391/mbi.2017.8.2.02

George CJ, Athanassiou VA, Boulos I (1963) The fishes of the coastal waters of Lebanon. Miscellaneous Papers in the Natural Sciences, the American University of Beirut 2: 1-149.

Golani D (2010) Colonization of the Mediterranean by Red Sea fishes via the Suez Canal - Lessepsian migration. In: Golani D, Ap-
pelbaum-Golani B (Eds) Fish Invasions of the Mediterranean Sea: Change and Renewal. Pensoft Publisher, Sofia-Moscow, 145-188.

Golani D, Fricke R (2018) Checklist of the Red Sea Fishes with delineation of the Gulf of Suez, Gulf of Aqaba, endemism and Lessepsian migrants. Zootaxa 4509(1): 001-215. https://doi.org/10.11646/ zootaxa.4509.1.1

Golani D, Appelbaum-Golani B, Gon O (2008) Apogon smithi (Kotthaus, 1970) (Teleostei: Apogonidae), a Red Sea cardinalfish colonizing the Mediterranean Sea. Journal of Fish Biology 72(6): 1534-1538. https://doi.org/10.1111/j.1095-8649.2008.01812.x

Golani D, Orsi-Relini L, Massuti E, Quignard J-P, Dulčić J, Azzurro E (2013) CIESM atlas of exotic fishes in the Mediterranean. Check list of exotic species. Available at: http:/www.ciesm.org/atlas/appendix 1.html

Gon O (1986) Apogonidae. In: Smth MM, Heemstra PC (Eds) Smith’s Sea Fishes. Macmillan South Ltd, Johannesburg, South Africa, 546-561.

Gon O (2000) The taxonomic status of the cardinalfish species Apogon niger, A. nigripinnis, A. pharaonis, A. sialis, and related species (Perciformes: Apogonidae). JLB Smith Institute of Ichthyology, Special Publication 65: 1-20.

Gon O, Randall JE (2003) A review of the cardinalfishes (Perciformes: Apogonidae) of the Red Sea. Smithiana. Publications in Aquatic Biodiversity Bulletin 1: 1-46.

Goren M, Yokes MB, Galil BS, Diamant A (2009a) Indo-Pacific cardinal fish in the Mediterranean Sea-New records of Apogon smithi from Turkey and $A$. queketti from Israel. Marine Biodiversity Records 2: e95. https://doi.org/10.1017/S1755267209001134

Goren M, Galil BS, Diamant A, Gayer K, Stern N (2009b) First record of the Indo-Pacific cardinal fish Apogon fasciatus (White, 1790) in the Mediterranean Sea. Aquatic Invasions 4(2): 409-411. https://doi. org/10.3391/ai.2009.4.2.21

Haas G, Steinitz H (1947) Erythrean fishes on the Mediterranean coast of Palestine. Nature 160(4053): 28. https://doi.org/10.1038/160028b0

Iglésias SP, Frotté L (2015) Alien marine fishes in Cyprus: Update and new records. Aquatic Invasions 10(4): 425-438. https://doi. org/10.3391/ai.2015.10.4.06

Irmak E, Engin S (2015) A newly established population of the Indian Ocean twospot cardinalfish, Cheilodipterus novemstriatus (Rüppell, 1838), in the northern Levantine Sea (Osteichthyes: Apogonidae). Zoology in the Middle East 61(2): 186-188. https://doi.org/10.1080 /09397140.2015.1035009

Katsanevakis S, Wallentinus I, Zenetos A, Leppäkoski E, Çinar ME, Oztürk B, Grabowski M, Golani D, Cardoso AC (2014) Impacts of invasive alien marine species on ecosystem services and biodiversity: A pan-European review. Aquatic Invasions 9(4): 391-423. https://doi.org/10.3391/ai.2014.9.4.01

Katsanevakis S, Zenetos A, Corsini-Foka M, Tsiamis K (2020) Biological invasions in the Aegean Sea: Temporal trends, pathways, and impacts. In: The handbook of environmental chemistry. Springer, Berlin, Heidelberg, 24 pp. https://doi.org/10.1007/698_2020_642

Mater S, Kaya M (1987) Türkiye'nin Akdeniz sularında yeni kaydedilen üç balık türü, Sudis hyalina Rafinesque, Pelates quadrilineatus (Bloch), Apogon nigripinnis Cuvier (Teleostei), hakkında. DoğaTürk Zooloji Dergisi 11(1): 45-49. [In Turkish]

Norman JR (1927) XXV. Report on the fishes. In: Cambridge expedition to the Suez Canal, 1924. Transactions of the Zoological Society of London 22(3): 375-389. https://doi.org/10.1111/j.1096-3642.1927. tb00386.x 
Osca D, Tanduo V, Tiralongo F, Giovos I, Almabruk SA, Crocetta F, Rizgalla J (2020) The Indo-Pacific sergeant Abudefduf vaigiensis (Quoy \& Gaimard, 1825) (Perciformes: Pomacentridae) in Libya, south-central Mediterranean Sea. Journal of Marine Science and Engineering 8(1): 14. https://doi.org/10.3390/jmse8010014

Öz MI, Erdogan O, Yuksek A (2007) Notes on the Erythrean alien fishes of Datca-Bozburun peninsula - a specially protected area in the south eastern Aegean Sea (Turkey). Rapports Commission Internationale Mer Méditerranée 38: 563.

Ragheb E, Akel EHKh, Rizkalla SI (2019) Analyses of the non-target catch from the Egyptian Mediterranean trawlers, off Port Said. The Egyptian Journal of Aquatic Research 45(3): 239-246. https://doi. org/10.1016/j.ejar.2019.07.003

Ragkousis M, Abdelali N, Azzurro E, Badreddine A, Bariche M, Bitar G, Crocetta F, Denitto F, Digenis M, El Zrelli R, Ergenler A, Fortič A, Gerovasileiou V, Grimes S, Katsanevakis S, Koçak C, Licchelli C, Loudaros E, Mastrototaro F, Mavrič B, Mavruk S, Miliou A, Montesanto F, Ovalis P, Pontes M, Rabaoui L, Sevingel N, Spinelli A, Tiralongo F, Tsatiris A, Turan C, Vitale D, Yalgin F, Yapici S, Zenetos A (2020) New alien Mediterranean biodiversity records (October 2020). Mediterranean Marine Science 21(3): 631-652. https://doi.org/10.12681/mms.23673

Rothman B-SS, Goren M, Galil BS (2013) Cheilodipterus novemstriatus (Rüppell, 1838) along the Levantine coast of the Mediterranean Sea: A forthcoming invasion? BioInvasions Records 2(1): 85-88. https://doi.org/10.3391/bir.2013.2.1.15

Roy H, Groom Q, Adriaens T, Agnello G, Antic M, Archambeau A, Bacher S, Bonn A, Brown P, Brundu G, López B, Cleary M,
Cogălniceanu D, de Groot M, De Sousa T, Deidun A, Essl F, Fišer Pečnikar Ž, Gazda A, Gervasini E, Glavendekic M, Gigot G, Jelaska S, Jeschke J, Kaminski D, Karachle P, Komives T, Lapin K, Lucy F, Marchante E, Marisavljevic D, Marja R, Martín Torrijos L, Martinou A, Matosevic D, Mifsud C, Motiejūnaitė J, Ojaveer H, Pasalic N, Pekárik L, Per E, Pergl J, Pesic V, Pocock M, Reino L, Ries C, Rozylowicz L, Schade S, Sigurdsson S, Steinitz O, Stern N, Teofilovski A, Thorsson J, Tomov R, Tricarico E, Trichkova $\mathrm{T}$, Tsiamis K, van Valkenburg J, Vella N, Verbrugge L, Vétek G, Villaverde C, Witzell J, Zenetos A, Cardoso A (2018) Increasing understanding of alien species through citizen science (Alien-CSI). Research Ideas and Outcomes 4: e31412. https://doi.org/10.3897/ rio.4.e31412

Sbaihi M, Saad A (1995) The existence of 4 immigrant fish species from the Red sea in the Syrian coast (the oriental Mediterranean). Rapports Commission Internationale Mer Méditerranée 34: 257.

Shakman E, Eteayb K, Taboni I, Ben Abdalha A (2019) Status of marine alien species along the Libyan coast. Journal of the Black Sea/Mediterranean Environment 25(2): 188-209.

Smith MM (1961) Fishes of the family Apogonidae of the western Indian Ocean and the Red Sea. Ichthyological Bulletin Rhodes University, South Africa 22: 373-418.

Zachariou-Mamalinga H (1990) The fishes of Symi, Dodecanese. Their scientific, vernacular, common modern Greek and ancient Greek names. Annales Musei Goulandris 8: 309-416.

Zenetos A, Galanidi M (2020) Mediterranean non indigenous species at the start of the 2020s: Recent changes. Marine Biodiversity Records 13(1): 10. https://doi.org/10.1186/s41200-020-00191-4 